QUADERNS DE FILOSOFIA VOL. III NÚM. I (20I6): 9I-IO6

ISSN: 234I-I4I 4 eISSN: 234I-3042 DOI: I0.7203/QFIA.3.I.7085

JOAN B. LLINARES

Universitat de València

\title{
Silencio y música en los Lager. Lectura de la Trilogía de Auschwitz de Primo Levi ${ }^{1}$
}

Recibido: 1/9/15. Aceptado: 25/1/16

Resumen: A partir de una detallada lectura de los tres libros de P. Levi sobre Auschwitz, este estudio elabora un esquema de los diferentes tipos de silencio que se pueden detectar en los Lager, así como el que se requiere para que podamos estar a la escucha del más insoportable y estremecedor de todos, el de los musulmanes y las víctimas. A continuación se analizan la presencia y las funciones que cumplía la música en tales lugares, destacando su aspecto odioso y degradante (las orquestas para el desfile de los presos) y también su rostro expresivo y solidario (los copleros y las canciones).

Abstract: From a careful reading of P. Levis's three books on Auschwitz, this study draws an outline of the different types of silence that can be detected in the "Lager", as well as the silence required for us to be attentive to the most unbearable and shocking of all, the Muslims' and the victims' silence. Then we analyze the presence and functions of the music performed in such places, highlighting its odious and degrading appearance (the bands for the prisoners parade) and its expressive and solidary face (the folk singers and songs).

Palabras clave: silencio, música, deshumanización, humanismo, arte, libertad. Keywords: silence, music, dehumanization, humanism, art, freedom.

${ }^{1}$ Aunque este texto se presentó analizando también otros testimonios, por ejemplo, los de Jean Améry, Jorge Semprún y Robert Antelme, así como destacando asimismo la importancia de la palabra y la poesía en los Lager, por cuestiones de espacio aquí nos limitaremos a los tres 
P RIMO LeVi emprendió la escritura de sus textos sobre la deportación a Auschwitz y la trágica suerte de los prisioneros en ese Lager, exponiendo cómo las vivió y lo que le enseñaron, movido por estos propósitos: "dar testimonio" de lo allí ocurrido (III, 14) y de ese modo satisfacer esa necesidad interior que le impulsaba a que "los demás" lo supiesen y que el horror sufrido no quedara en el olvido (I, 10), y a "proporcionar documentación para un estudio sereno de algunos aspectos del alma humana" (I, 9). En lo que sigue quisiéramos concentrarnos en su testimonio, de reconocida y excepcional calidad, porque aporta experiencias y conocimientos sobre el ser humano que permiten ampliar y profundizar nuestra reflexión sobre las complejas realidades que aquí nos convocan: el silencio y la música en tales ámbitos de extrema maldad. Como dijo al referirse a un caso límite de comunicación necesaria y fallida, el del niño Hurbinek, "también bajo este aspecto el Lager era un laboratorio cruel en el cual podía asistirse a situaciones y comportamientos nunca vistos antes, ni después, ni en otra parte" (III, 83). Deberemos, por tanto, alcanzar una actitud de silencio para poder estar atentos a sus palabras y, sin caer en los hechizos del morbo y las venganzas, mantener la serenidad a lo largo de nuestra lectura.

\section{Para una tipología de los Silencios en y ante Auschwitz}

Hay un silencio injusto e insoportable, el silencio más terrible e irreversible de todos los que Levi tuvo que presenciar y que, como una necesidad elemental, le empujó a escribir, porque casi todos los italianos e italianas que estuvieron forzados a viajar con él a Auschwitz jamás pudieron regresar a su país para contarlo; no tuvieron periplos de retorno porque habían sido asesinados de diversas formas: es el estremecedor silencio de quienes ya habían muerto cuando los soldados de los ejércitos aliados llegaron a los Lager, el silencio de las victimas, convertidas en humo para siempre.

Ese genocidio había sido programado: por parte de las autoridades nazis se había tratado de borrar sistemáticamente todo recuerdo de aquellas existencias, de ahí que ordenaran hacer desaparecer incluso sus cadáveres, reducidos a cenizas que luego se esparcían por las tierras de cultivo como abono

libros de Primo Levi que componen la denominada Trilogía de Auschwitz del escritor italiano, a saber, Levi, P. 1987, Si esto es un hombre; 1988, La tregua y 1989, Los hundidos y los salvados, Barcelona: Muchnik Editores [trad. cast. Pilar Gómez Bedate]. Para evitar excesivas notas a pie de página, entre paréntesis y en números romanos indicamos la procedencia de los textos citados de cada uno de estos libros (I, II y III, respectivamente), y luego indicamos la página o páginas correspondientes de esas ediciones castellanas. 
para los girasoles. Ese silencio impuesto nos sobrecoge en los Lager y ante los crematorios, porque esos lugares, convertidos en memoriales, reclaman a su vez meditación en silencio, recuerdo hondo sin imágenes que trivialicen aquel crimen, y lectura responsable de los testimonios de los sobrevivientes. Aquel silencio selló la boca de varios millones de personas, y nos obliga a guardar silencio por nuestra parte, a recordarlas mediante ese difícil silencio que nos aleje de ruidos e interferencias y, estando a la escucha, esforzarnos por aprender la lección que las víctimas proclaman desde su penetrante vacío: que los genocidios no se repitan, que no vuelva a haber cámaras de gas, que se repare aquella atroz injusticia. He aquí, pues, dos primeras modalidades de silencio a registrar: la que requiere la meditación y la memoria viva de lo que Auschwitz significa, y la de las víctimas silenciadas a la fuerza, víctimas que ni siquiera reposan en tumbas anónimas y no pudieron darnos su testimonio porque se les arrebató la palabra y la vida.

Ahora bien, antes de ese silencio final ya hubo otro silencio previo en forma de amenaza aplastante cuando esas víctimas todavía estaban vivas, pues se las separó por completo del resto de los humanos, de manera que no pudieran, de ningún modo, hablar con nadie ni contar la horrorosa pesadilla que estaban sufriendo, narrar los abusos que padecían, ni documentar su existencia de prisioneros ultrajados, para que esa porción de su vida deportada, y la muerte que se les dio poco después, quedaran silenciadas y, en consecuencia, ignoradas por todos. Como afirmaban cínicamente los soldados de las SS, "ninguno de vosotros quedará para contarlo" (III, 11). Es el silencio del gueto $y$ de la exclusión.

En determinados casos y para determinados colectivos esta amenaza se cumplió literalmente, pues, dice Levi que en las minas de los Lager "las condiciones eran las mismas que llevaban a la muerte a los esclavos de guerra de los romanos y a los indios sojuzgados por los españoles; eran mortíferas, hasta el punto de que no ha habido nadie que haya vuelto para contarlas" (III, 89). Ciertamente, tampoco ha podido contar nadie la experiencia de morir en una cámara de gas, tal tipo de muerte, como toda muerte, sella para siempre la boca de quien ha abandonado el mundo de los vivos. He aquí un límite infranqueable de todo testimonio de los sobrevivientes que algunos negacionistas han querido aprovechar.

Antes de sufrir la muerte física, en los campos se producía una tremenda deshumanización que dejaba sin palabras a los deportados, los hundía en un silencio letal, les provocaba una degradante mudez. Esta es, pues, otra modalidad, el silencio por denegación de la palabra, que afecta a quienes desde su entrada en los Lager eran muertos vivientes, porque a los humanos se nos puede maltratar de forma extrema reduciéndonos al silencio, basta con 
que se nos niegue sistemáticamente la palabra y se nos someta a una brutal incomunicación. Levi afirma que los prisioneros eran sometidos a un tipo de incomunicación salvaje que no tiene parangón con la que sufre un turista de visita en país de lengua para él incomprensible, pues con facilidad satisface sus necesidades básicas, siempre encuentra carteles, palabras en inglés, o gestos que posibilitan la comprensión de los mensajes. Ni siquiera es comparable con la que vive un emigrante que busca trabajo, pues la incomunicabilidad de los prisioneros en un campo era más radical, sobre todo si desconocían cualquier noción de alemán: en tales casos los miembros de las SS eran especialmente despreciativos y repetían sus órdenes "en voz alta y rabiosa, después de un alarido estremecedor, como si se dirigiesen a un sordo o a un animal doméstico más sensible al tono que al contenido del mensaje" (III, 79). Eran los feroces "rugidos de los Kapos y de las SS" (III, 84). En tal jauría, si por no entender y estar aterrorizados se dudaba y no se sabía qué hacer, "llovían los golpes, y estaba claro que se trataba de una variante del mismo lenguaje: el uso de la palabra para comunicar el pensamiento, ese mecanismo necesario y suficiente para que el hombre sea hombre, había caído en desuso. Era una señal: para aquellos, no éramos ya hombres; con nosotros, como con las mulas y las vacas, no existía una diferencia sustancial entre el grito y el puñetazo" (III, 79-80). Coherentemente con ello, en Mauthausen, un Lager muy políglota, "al látigo de goma se le llamaba Dolmetscher, el intérprete: el que se hacía entender por todos" (III, 80). Allí había solo berridos y golpes en lugar de palabras.

Para los alemanes nazis, como para los antiguos griegos, quien no hablaba ni entendía alemán era un bárbaro; "si se obstinaba en tratar de expresarse en su lengua, o mejor, en su no-lengua, había que hacerle callar a patadas y ponerlo en su sitio, a tirar de algo, llevar algo o empujar algo, porque no era un Mensch, un ser humano" (III, 80). La meta de ese maltrato era previsible, el conjunto de presos se tornaba un "rebaño mudo innumerable" (I, 126), forzado a mantenerse en silencio.

Esta deshumanización por negación de la palabra producía lesiones muy graves: "Sentirse seres a quienes no se hablaba tenía efectos rápidos y devastadores. A quien no te habla, o se dirige a ti con alaridos que te parecen inarticulados, no osas dirigirle la palabra. Si tienes la suerte de encontrar a tu lado a alguien con quien tienes una lengua en común, menos mal, podrías cambiar impresiones, aconsejarte con él, desahogarte; si no encuentras a nadie, la lengua se te seca en pocos días, y con la lengua el pensamiento" (III, 81). Además, al no entender ni las órdenes, ni las obligaciones y prohibiciones, uno se siente en el vacío y descubre que la comunicación genera información, y que sin información no se puede vivir, de hecho muchos prisioneros que no entendían 
aquel alemán reducido a jerga miserable ${ }^{2}$ murieron ya en los primeros diez o quince días de estancia en el Lager por tal carencia de información vital: se les había convertido en "nuevos sordomudos", en "animales cogidos en una trampa” (III, 83). Este drama lingüístico-antropológico provocaba toda una cruel proliferación de "hundidos", los denominados musulmanes, los prisioneros irreversiblemente exhaustos y extenuados, próximos a la muerte: "De la comunicación fallida o difícil no sufríamos todos en la misma medida. La carencia de sufrimiento, la aceptación del eclipse de la palabra, era un síntoma fatal: señalaba que la indiferencia definitiva se estaba aproximando" (III, 88). De ahí que una de las definiciones fundamentales de los llamados "musulmanes" sea la siguiente: son "no-hombres que marchan y trabajan en silencio" (I, 96).

Todos los deportados corrían el riesgo de perder la lengua y el pensamiento, de hecho cuando Levi quiere explicar sus recuerdos de los primeros días en Auschwitz, la imagen que utiliza es la de un absurdo y chirriante cine sonoro pero extrańamente mudo, sin palabras ni nombres propios: "En la memoria de todos nosotros, los sobrevivientes, escasamente políglotas, los primeros días de Lager han quedado grabados en forma de película desenfocada y frenética, llena de ruido y de furia, y carente de significado: un ajetreo de personajes sin nombre ni rostro sumergidos en un continuo y ensordecedor ruido de fondo del que no afloraba la palabra humana. Una película en blanco y negro, sonora pero no hablada" (III, 81). La evidente intertextualidad shakespeareana en el seno de una poderosa metáfora cinematográfica subraya la universalidad de este rasgo experiencial coetáneo.

Otro efecto de "este vacío desprovisto de comunicación" es el recuerdo acústico de palabras y frases en lenguas desconocidas que funcionaban como señales y se han grabado en la memoria de los sobrevivientes como "en una cinta magnética vacía" (III, 82). "Eran fragmentos arrancados a lo indiferenciable", recortes de sentido dentro de la insensatez, trocitos de alimento para

\footnotetext{
${ }^{2}$ Resulta extraño que P. Levi, que durante sus estudios y para su tesis había consultado bibliografía alemana, prácticamente no entendiera nada y pagara con su escaso pan "lecciones particulares y aceleradas" de ese idioma para poder sobrevivir en Auschwitz, pero tal incomprensión es perfectamente explicable porque "el alemán del Lager, descarnado, gritado con alaridos, sembrado de obscenidades e imprecaciones, solo tenía una vaga semejanza con el lenguaje exacto y austero" tanto de los libros de química como de la poesía de Heine que le recitaba una compañera de estudios, era "una lengua aparte", una variante de la LTI, la "lengua del Tercer Reich", como la denominó V. Klemperer, repleta de siglas. De las importantes consideraciones de filólogos y lingüistas sobre dicho fenómeno preferimos resaltar la decisiva observación antropológica de que "donde se violenta al hombre se violenta también el lenguaje" (III, 85). "En el archipiélago del Lager alemán se había delineado un lenguaje sectorial, una jerga, el Lagerjargon, dividido en las subjergas características de todo Lager, y estrechamente emparentado a las viejas jergas de los cuarteles prusianos y al reciente alemán de las SS", un idioma de términos fácilmente comparables con los que se utilizaban en ruso en el Archipiélago Gulag.
} 
un cerebro subalimentado, inconsciente preparación para lo que podría venir después, un universo diseñado sin espacios para las palabras y el diálogo.

El silencio también puede significar la anulación de toda comunicación escrita, la ausencia de todo mensaje epistolar, el correo proscrito. A diferencia de lo que pasaba con otros prisioneros, por ejemplo, los denominados "políticos", en los Lager a los judíos, considerados impuros y sembradores de impureza, "se les vedaba la comunicación más preciosa: con sus países de origen y su familia” (III, 89); esa prohibición era un corte que generaba mucho sufrimiento, como el del exilio; era la amputación de un nervio, de amargas consecuencias, pues de ello nace "una mortal impresión de abandono y también un resentimiento injusto", ya que se acusa sin fundamentos a quienes están libres de que no nos escriban y nos hayan abandonado. Se tiene entonces la ocasión de aprender, indica Levi, que "en el gran continente de la libertad, la de la comunicación es una provincia importante", y ello no solo a nivel individual, sino también social, pues, en los países en que está vedada la comunicación, "todas las demás libertades languidecen" (III, 90). Se forma entonces un duro círculo vicioso de intolerancia y de censura que se alimentan mutuamente de forma dañina. Quedarse al margen de la comunicación es sentirse tristemente diferentes, extraños, exiliados del propio país e incluso del género humano. La alternativa, por desgracia, todavía hubiera sido peor, pues si a los deportados judíos se les hubiera permitido escribir cartas, proporcionándoles papel y lápiz, la empresa hubiera fracasado ante la censura porque sus pocos familiares vivos estaban escondidos, y consignar información sobre ellos hubiera sido delatar su existencia y facilitar su captura. Intercambiar correo con la familia era tarea prohibida y secreta, solo posible gracias a personas amigas que asumían graves riesgos, por ello mismo esa comunicación excepcional cobraba vital relevancia. Levi lo reconoce: "sé que eso ha sido uno de los factores que me han permitido sobrevivir” (III, 90).

Los Lager han generado otras formas de silencio que merecen especial atención: muchos de entre los que tuvieron la fortuna de ser liberados se han mantenido después expresamente en silencio, jamás han querido hablar de aquel trauma de insoportable dolor, aunque hayan sobrevivido décadas. Así pues, hay también un silencio sostenido ante aquella maldad. En Los hundidos $y$ los salvados el escritor italiano dice que quienes han pasado por experiencias crueles se dividen en dos categorías bien diferenciadas, con raros matices intermedios: "los que se callan y los que hablan" (III, 128). Ambos tienen razones válidas para su comportamiento, callan los que sufren más profundamente ese malestar llamado "vergüenza", los que no se sienten en paz con ellos mismos, o cuyas heridas sangran todavía. Y hablan quienes reconocen en su prisión el centro de su vida, el acontecimiento que les ha marcado la existencia entera; 
hablan porque saben que han sido testigos de un acontecer de dimensiones planetarias y seculares; hablan porque es bello contar las desdichas pasadas, como hizo Ulises en la corte de los feacios, y de ese modo afirman su identidad y sienten aumentado su prestigio; y hablan, en fin, porque se les invita a hacerlo, se les propone que cuenten la singularidad de su experiencia y den testimonio de la historia personal que vivieron. Para comprender la primera opción importa saber qué significa la "vergüenza" en la vida de los sobrevivientes, porque varios de ellos, incluso tras haber dado su testimonio personal de viva voz y por escrito, luego han escogido la muerte voluntaria, esto es, el silencio definitivo que desde entonces comparten con el resto de las víctimas. Quede aquí abierta esta importante cuestión, que está conectada con una particular vivencia del silencio en el Lager, a la que podríamos denominar el silencio avergonzado. Veamos al menos su silueta.

Permanecer callados no casa con escuchar el grito de la voz de la conciencia y mantener la boca cerrada, esa contradicción produce heridas en las almas nobles, y aunque sea perfectamente comprensible y aceptable tal actitud reservada en aquel infierno repleto de absurdos e injusticias, su recuerdo no cicatriza ni desaparece, al contrario, acrecienta el malestar y corroe la frágil paz del presente. La vergüenza surgía muy pronto entre los deportados: ya el primer día que pasa Levi en el Lager un judío alemán traduce a un grupo de italianos las palabras de un alférez que les manda callar porque "esto no es una escuela rabínica" (I, 25); ese judío se pliega de muy mala gana a traducir lo que se le ordena y no quiere transmitir las incesantes preguntas de los recién ingresados, sabe que eso es inútil, minutos después ese preso se va "y nosotros ahora estamos callados, aunque nos avergoncemos un poco de estar callados" (I, 26). Tragarse los legítimos interrogantes que surgen ante un entorno nuevo y desconcertante es una clara renuncia a la humanidad que nos constituye, por eso tal silencio autoimpuesto, o tales palabras reprimidas y nunca expresadas, producen vergüenza: delatan que no nos atrevemos a asumir las demandas y los riesgos básicos que nuestra condición conlleva.

Esa desconsoladora sensación de humanidad amputada es mucho más hiriente si por prudencia elemental nos mantenemos callados ante una injusticia flagrante, por ejemplo, ante el asesinato de una persona valiente, o si no tenemos más remedio que fingir con nuestras palabras que consentimos y aprobamos tal vileza, como relata Levi con amargura:

Una vez que todos los Kommandos han vuelto, la banda se ha parado de golpe, y una ronca voz alemana ha impuesto silencio. De la improvisada quietud se ha levantado otra voz alemana, y en el aire oscuro y enemigo ha hablado durante mucho tiempo coléricamente. [...] Cuando terminó el discurso del alemán, que 
nadie pudo entender, de nuevo se elevó la primera voz ronca: Habt ihr verstanden? (¿Lo habéis entendido?)

¿Quién respondió, Jawohl? Todos y ninguno: fue como si nuestra maldita resignación tomase cuerpo de por sí, se hiciese voz colectivamente por encima de nuestras cabezas. Pero todos oyeron el grito del moribundo, éste traspasó las gruesas y antiguas barreras de inercia y de sumisión, golpeó el centro vivo del hombre en cada uno de nosotros:

—Kamaraden, ich bin der Letzte! (¡Compañeros, yo soy el último!)

Me gustaría poder contar que entre nosotros, rebańo abyecto, se hubiese levantado una voz, un murmullo, un signo de asentimiento. Pero no sucedió nada. Hemos continuado en pie, encorvados y grises, con la cabeza inclinada, y no nos hemos descubierto la cabeza más que cuando el alemán nos lo ha ordenado. El escotillón se ha abierto, el cuerpo se ha deslizado atrozmente; la banda ha vuelto a tocar, y nosotros, de nuevo formados en columna, hemos desfilado ante los últimos temblores del moribundo (I, 155-7)

Todavía queremos enumerar una última modalidad de silencio, la que debe respetar sobre todo quien ha optado por dar testimonio de aquella lacerante deportación, como hizo Levi, el silencio reservado, el que procede de la sabiduría que enseña que no se debe contar todo a todos, pues cada vida humana esconde secretos que no se revelan a cualquiera y que uno mismo tiene dificultades en reconocer. Esta reserva atañe a la discreción que hay que guardar al relatar momentos vividos que son íntimos y personalísimos, momentos singulares de extrema tensión en que también intervinieron otras personas y que sería obsceno y desleal detallar: "Muchas cosas dijimos e hicimos entonces de las cuales es mejor que no quede el recuerdo" (I, 16). "Nos contamos entonces, en aquel momento decisivo, cosas que entre vivientes no se dicen. Nos despedimos, y fue breve" (I, 19). Estos silencios subrayados y explícitos son, por ello mismo, sumamente elocuentes.

Aún cabría documentar una faceta de la experiencia de Auschwitz que algunos estudiosos, sobre todo teólogos, han denominado el silencio de Dios. En el caso de P. Levi, judío no creyente, este silencio quizá esté ya acusado cuando ridiculiza el miope egoísmo de la plegaria de acción de gracias de cierto preso que parece insensible a la tragedia que han de sufrir en silencio quienes han sido seleccionados por los nazis para ir a las cámaras de gas:

Ahora [...] la jornada ha terminado. Poco a poco, prevalece el silencio y entonces, desde mi litera que está en el tercer piso, se ve y se oye que el viejo Kuhn reza, en voz alta, con la gorra en la cabeza y oscilando el busto con violencia. Kuhn da gracias a Dios porque no ha sido elegido. 
Kuhn es un insensato. ¿No ve, en la litera de al lado, a Beppo el griego que tiene veinte años y pasado mañana irá al gas, y lo sabe, y está acostado y mira fijamente a la bombilla sin decir nada y sin pensar en nada? ¿No sabe Kuhn que la próxima vez será la suya? ¿No comprende Kuhn que hoy ha sucedido una abominación que ninguna oración propiciatoria, ningún perdón, ninguna expiación de los culpables, nada, en fin, que esté en poder del hombre hacer, podrá remediar ya nunca?

Si yo fuese Dios, escupiría al suelo la oración de Kuhn (I, 137)

\section{LA DOBle FAZ DE MÚSICA EN LOS LAGER}

Pasemos ahora a enumerar algunas de las insospechadas lecciones que los campos de trabajo y exterminio nos dan sobre la música, este singular y enigmático arte de los sonidos que puede llegar allí donde no alcanzan las palabras, un arte que permite enaltecer el silencio y crear "música callada", tan riguroso como las matemáticas y tan emotivo como las lágrimas, capaz de amansar a las fieras y de elevarnos a las más altas esferas del humanismo y la libertad, como subrayó la estética a partir de las valoraciones de los románticos. Curiosamente, este arte ha tenido compositores excepcionales y especial cultivo y sensibilidad en ese ámbito histórico y geográfico del que procedían los nazis, la cultura germánica y sus peculiares gustos, celebraciones y rituales, en los que siempre está presente la música de forma principal.

Sí, con férrea coherencia con tal rasgo etnológico, también la había en aquellos parajes desalmados, aunque eso parezca contradictorio con la supuesta excelencia de lo musical: también nosotros tendemos a pensar que es imposible que fuera cierta la información que pudieron oír los prisioneros a las pocas horas de llegar a Auschwitz: "Dice que todos los domingos hay conciertos" (I, 27). ¿Cómo, había fragmentos de civilización en tamaña barbarie? ¿Acaso son compatibles los Lager y el arte de Orfeo, los infectos barracones de presos e incluso los caminos que llevaban a las cámaras de gas, y la existencia de exquisitas orquestas? No solo son compatibles, sino que se reforzaban mutuamente, y, como el resto de los allí encerrados, el escritor italiano sufrió las consecuencias de tan asombrosa presencia. Gracias a su memoria sutil y a su aguda capacidad de autoanálisis, en sus textos la ha sabido describir con finura e incluso ha brindado su matizada explicación de ese extraño fenómeno: para él era obvio que en muchos de sus aspectos más penosos y absurdos, la existencia de bandas y orquestas en los Lager se derivaba de las premisas y paradojas de aquel sistema totalitario y devastador: 
el mundo concentracionario no era sino una versión, una adaptación de la praxis militar alemana. El ejército de los prisioneros del Lager tenía que ser una copia sin gloria del ejército propiamente dicho o, mejor dicho, una caricatura suya. [...] Un ejército desfila a paso militar, en orden cerrado, al son de una banda: por ello, también en el Lager tiene que haber una banda, y el desfile tiene que ser un desfile que siga las reglas del arte, con el giro a la izquierda ante la tribuna de las autoridades al son de la música. Este ceremonial es tan necesario, tan evidente, que llega a prevalecer sobre la legislación antijudía del Tercer Reich. Con sofisticación paranoica, ésta prohibía a las orquestas y los músicos judíos que tocasen partituras de autores arios para que éstos no fuesen contaminados. Pero en los Lager de los judíos no había músicos arios, ni tampoco hay muchas marchas militares que hayan sido escritas por compositores judíos; por lo cual, derogando las leyes de pureza, Auschwitz era el único lugar alemán donde los músicos judíos podían, incluso debían, tocar música aria: la necesidad está por encima de la ley (III, 100)

Así sucedía en Auschwitz, y P. Levi lo documenta con claridad: a los pocos meses de entrar en el Lager casi todos los prisioneros habían ya desaparecido, "quedaban solamente los médicos, los sastres, los zapateros remendones, los músicos, los cocineros, los jóvenes homosexuales atractivos, los amigos y paisanos de alguna autoridad del campo; además de individuos particularmente crueles, vigorosos e inhumanos [...]” (I, 95). Así pues, y a diferencia de la triste suerte que corrían otro tipo de profesionales liberales, de intelectuales y artistas, los músicos, esto es, los buenos intérpretes e instrumentistas, los directores, compositores y arreglistas, e incluso los copistas, podían subsistir en el Lager; allí no vivían dedicados a la música, sino que sobrevivían más bien gracias a la música, explotando los insospechados poderes demoníacos de este arte ambivalente, tan fascinante y a la vez tan peligroso. El escritor italiano describe con su proverbial acierto el tragicómico espectáculo que tuvieron que presenciar el día de su llegada a Auschwitz:

Una banda empieza a tocar junto a la puerta del campo: toca Rosamunda, la famosa canción sentimental, y nos parece tan extraño que nos miramos sonriendo burlonamente; surge en nosotros un amago de alivio, puede que todas estas ceremonias no sean más que una payasada colosal al gusto germánico. Pero la banda, al terminar Rosamunda, sigue tocando otras marchas, una tras otra, y he aquí que aparecen los pelotones de nuestros compañeros que vuelven del trabajo. Vienen en columnas de cinco: tienen un modo de andar extraño, inhumano, duro, como fantoches rígidos que solo tuviesen huesos: pero andan marcando escrupulosamente el tiempo de la música (I, 31) 
Pronto tuvo que comprobar que eso era lo habitual, que él mismo tendría que desfilar un día y otro día al compás de esas canciones sentimentales: "Con toda normalidad, a partir de las trece en punto, el taller se vacía y la formación gris e interminable desfila durante dos horas hacia los dos puestos de control, donde como todos los días somos contados y recontados, ante la orquesta que, durante horas sin interrupción, toca como todos los días las marchas con las que, a la entrada y a la salida, debemos sincronizar nuestros pasos" (I, 134).

Sin embargo, las perversas funciones que cumplía aquella banda con sus marchas y su presencia cotidiana eran difíciles de captar, pues cuando uno es un anodino prisionero-trabajador-forzado, que desfila junto a sus compañeros al son de aquellas canciones, no puede sino seguir el ritmo sin desentonar, sin dejar de marcar el paso, entre otras cosas para evitar dar algún traspiés o salirse de la fila, y recibir de inmediato duros golpes y castigos por el desorden provocado. Pero si se tiene la oportunidad de observar ese desfile paramilitar a distancia, por ejemplo, desde una de las ventanas de la enfermería, aunque ello comporte que apenas se perciban las melodías de las canciones que la banda está interpretando, entonces poco a poco se descubre la maligna seducción que la música provoca en quienes están sometidos a su hechizo, por absurda que sea la jornada laboral que se avecina y por agotador que haya sido el trabajo realizado. Un espectador inteligente hasta imagina con acierto las consecuencias que tendrá ese reiterativo tratamiento acústico en su vida futura, si consigue tenerla, por la indestructible asociación de ideas que habrá cimentado en su psique. ${ }^{3}$ La cita es larga, pero su calidad documental la hace imprescindible:

Cuando llega la distribución del pan, se oye lejana, más allá de las ventanas, en el aire oscuro, la banda que empieza a tocar: son nuestros compańeros sanos que salen al trabajo en formación.

Desde el $\mathrm{Ka}-\mathrm{Be}$ no se oye bien la música: llega asiduo y monótono el martilleo del bombo y de los platillos, pero sobre su trama las frases musicales se dibujan tan solo a intervalos, a capricho del viento. Nosotros nos miramos unos a otros desde las camas, porque todos sentimos que esta música es infernal.

${ }^{3}$ Levi fue especialmente sensible a esta cualidad de la utilización de la música y de las señales acústicas para condicionar los reflejos y los recuerdos: "ese silbido lejano estoy seguro de que es real, no viene de la locomotora sońada, ha sonado objetivamente: es el silbido de la Decauville, viene de la cantera donde se trabaja también de noche. Una larga nota firme, después otra un semitono más baja, luego otra vez la primera, pero corta y truncada. Este silbido es algo importante: lo hemos oído tantas veces, lo hemos asociado tantas con el sufrimiento del trabajo y del campo, que se ha convertido en su símbolo y evoca directamente sus imágenes, como ocurre con algunas músicas y algunos olores" (I, 64). 
Los motivos son pocos, una docena, cada día los mismos, mañana y tarde: marchas y canciones populares que les gustan a todos los alemanes. Están grabadas en nuestras mentes, serán lo último del Lager que olvidemos: son la voz del Lager, la expresión sensible de su locura geométrica, de la decisión ajena de anularnos primero como hombres para después matarnos lentamente.

Cuando suena esta música sabemos que nuestros compañeros, afuera en la niebla, salen en formación, como autómatas; tienen las almas muertas y la música los empuja, como el viento a las hojas secas, y es un sustituto de su voluntad. La voluntad ya no existe: cada latido se convierte en un paso, en una contracción refleja de los músculos deshechos. Los alemanes lo han conseguido. Son diez mil y son solo una máquina gris: están determinados exactamente; no piensan y no quieren, andan.

Al desfile de salida y de entrada los SS no faltan nunca. ¿Qué podría negarles el derecho de asistir a esta coreografía montada por ellos mismos, a la danza de los hombres extintos, escuadra tras escuadra, en camino desde la niebla hacia la niebla? ¿Qué mejor prueba de su victoria?

También los del $\mathrm{Ka}-\mathrm{Be}$ conocen este ir y volver del trabajo, la hipnosis del ritmo interminable que mata el pensamiento y calma el dolor; lo han experimentado y volverán a experimentarlo. Pero es preciso salir del encantamiento, oír la música fuera como ocurría en el $\mathrm{Ka}-\mathrm{Be}$ o como la recordamos ahora, luego de la liberación y el renacimiento, sin obedecerla, sin sufrirla, para comprender lo que era; para comprender por qué calculada razón los alemanes habían creado este mito monstruoso y por qué, todavía hoy, cuando la memoria nos restituye alguna de aquellas inocentes canciones, se nos hiela la sangre en las venas y nos damos cuenta de que haber vuelto de Auschwitz no ha sido suerte pequeńa (I, 54-5)

Como ya indicó el músico y escritor P. Quignard en un ensayo fundamental sobre "el odio a la música", 4 la escueta escritura de P. Levi escoge precisas metáforas para dibujar los efectos sobre los humanos de esa "música infernal": los convierte en fantoches rígidos, en almas muertas, en hojas secas a merced del viento, en piezas de una gran maquinaria, en seres extintos que, como autómatas, participan en una coreografía alienada, en una locura geométrica. Si recordamos que los presos, rapados y esqueléticos, iban vestidos con incongruentes trajes a rayas, la imagen que de ellos nos formamos es bien obvia: unos lamentables peleles que parecen engranajes. La música de la orquesta del Lager mata el pensamiento, aniquila la voluntad, calma el dolor,

${ }^{4}$ Quignard, P. I998, El odio a la música. Diez pequeños tratados, Barcelona: Ed. Andrés Bello [trad. y notas de P. Jacomet, original francés de 1996], sobre todo el tratado séptimo titulado precisamente "El odio a la música", 191-228, en el que se cita expresamente a P. Levi. 
transforma el caminar en una cadena de actos reflejos. Esa música es un ritual que masifica, un instrumento que degrada y deshumaniza, un mecanismo para la marcha forzada, un arma para acallar la conciencia, una droga que insensibiliza, un somnífero que amordaza, un prolegómeno de la muerte. Fácil resulta comprender que su recuerdo resulte horrible por las pesadillas que provoca. Ante sus insidias estamos indefensos, pues, para decirlo con Quignard, "las orejas no tienen párpados", y, además, los sonidos persisten en nuestro interior. A veces las melodías estallan en la mente de forma involuntaria, causando mucho dolor en los más sensibles, por todo lo cual el odio que acarrea el arte de los sonidos resulta una respuesta justificada, acusa a la otra cara de esta esfinge: se sabe que incluso en las enfermerías de los campos los presos y las presas no soportaban oír la música más emotiva y cargada de recuerdos de infancia, como la de los días navideños, porque el dolor que les causaba al removerles la memoria y patentizarles su desgracia, les destrozaba el alma. ${ }^{5}$

Ahora bien, en los Lager no solo había música de bandas o de orquestas, organizadas por las autoridades nazis para sus siniestros propósitos, tanto públicos como privados, pues además de amenizar los desfiles de rigor, como ya hemos visto, los miembros de las SS obligaban a los prisioneros-músicos, convertidos en sus esclavos particulares, a que interpretaran piezas determinadas, e incluso a que estrenaran nuevas que fueran de su agrado, para festejar aniversarios de los comandantes, por ejemplo, o por mero gusto y capricho de sus mujeres y familiares, etcétera. No obstante, importa reconocer que hasta en los campos ese arte sublime, objeto de tan degradada manipulación, también motivó a notables compositores, judíos y no judíos, a dejar testimonio de su insobornable creatividad gracias a memorables partituras que podemos escuchar ahora, pues hay grabaciones de muchas de ellas, fruto de loables iniciativas que buscan reparar el daño y tratan de hacer justicia a lo que los miserables directivos de aquel régimen condenaron como "música degenerada". A otro

\footnotetext{
${ }^{5}$ Tampoco podemos extendernos al respecto, solo deseamos indicar que para abordar estas cuestiones son muy valiosos libros como el de Simon LAKs, director de una de aquellas orquestas, cuyo original polaco está traducido al inglés, al francés y al castellano (2009, Melodías de Auschwitz, Madrid: Arena Libros [Prólogo de Pierre Vidal-Naquet, Epílogo de André Laks, traducción de Xavier Farré Vidal]; el de Fania Fenelon 1982, Sursis pour l'orchestre. Témoignage recueilli par Marcelle Routier, París: Stock/Opera mundi; o el consagrado en 2003 por Richard Newman y Karen Kirtley a la violinista y directora de la orquesta de mujeres de Auschwitz, Alma Rosé, Vienna to Auschwitz, Pompton Plains y Cambridge: Amadeus Press. También merecen consulta otros ensayos que estudian la cuestión, p. ej., Gilbert, S. 20 io, La música en el Holocausto, Buenos Aires: Eterna cadencia [trad. de M. J. de Ruschi]; Brown, S. \& Volgsten, U. 2006, Music and manipulation: on the social uses and social control of music, Nueva York: Bergham Books. [Particularmente el ensayo de Joseph J. Moreno titulado "Orpheus in hell", que forma el capítulo 10.]
} 
nivel, y para deleite de los propios prisioneros, la vida en los campos propició la constitución de pequeños grupos clandestinos de música de cámara y de jazz, cuyas interpretaciones, a menudo en días festivos y en horarios de mínima vigilancia, reforzaban el sentido de la dignidad y la libertad de sus compañeros, como documentan los testimonios de algunos sobrevivientes, para el caso de Buchenwald el de Jorge Semprún es a este respecto muy valioso. ${ }^{6} \mathrm{Si}$ volvemos de nuevo a los textos de Levi y a su experiencia personal en Auschwitz, comprobaremos que él fue testigo de que en este Lager también se observaba la ineludible presencia de una de las manifestaciones musicales más universales y populares de los seres humanos de todas las culturas, fruto de la íntima unión de las palabras con las melodías en la voz humana: las canciones. En efecto, allí había copleros que eran capaces de condesar las vivencias colectivas en rimas improvisadas, como si fueran cronistas y cantautores que ejercían su arte tradicional pasando de barracón a barracón e interpretando para todos sus emocionantes coplas, de ese modo ellos se expresaban con sus poemas y su canto, mediante estos se comunicaban con sus compañeros de infortunio y les proporcionaban cierto consuelo, pues es manifiesto que se les escuchaba con respeto, con atención y con muestras de gratitud:

Por la portezuela de atrás, a escondidas y mirando alrededor con cautela, ha entrado el coplero. Se sienta en la litera de Wachsmann y en seguida reúne en torno una pequeña multitud atenta y silenciosa. Canta una interminable rapsodia en yiddish, siempre la misma, en cuartetas rimadas, de una melancolía resignada y penetrante (¿o tal vez es así como la recuerdo porque la oí entonces y en aquel sitio?); por las pocas palabras que entiendo, debe de ser una canción que ha compuesto él mismo en la que ha encerrado toda la vida del Lager con sus particularidades más pequeñas. Algunos se sienten generosos y remuneran al coplero con un pellizco de tabaco o una hebra de hilo; otros lo escuchan absortos, pero no le dan nada (I, 62)

En los textos de Levi hay más rastros significativos de la música como elemento vertebrador de la cultura popular incluso en aquellos parajes letales. $\mathrm{Su}$ enorme eficacia positiva es innegable, pues poder compartir la letra, la melodía y el ritmo de baile de una canción tradicional fraguaba y mantenía la fraternidad de determinados grupos nacionales, como el de los judíos de Salónica. Cantar con los compañeros formando un círculo vivo, entrelazando los brazos y moviendo a compás los pies, produce una dionisíaca sensación de éxtasis, una ebriedad que libera de la opresora cerrazón del Lager, saca de las fronteras

${ }^{6}$ Semprún, J. 2012, Le fer rouge de la mémoire, París: Gallimard. 
de la solitaria individualidad y genera solidaridad y espíritu de comunidad, esa mínima patria que sobre todo se necesita en territorio tan hostil y mortífero, de enconada lucha por la subsistencia, en el que parece que haya desaparecido toda opción para una conducta moral, es decir, para una conducta sencillamente humana:

Junto a nosotros hay un grupo de griegos, de esos admirables y terribles judíos salónicos, tenaces, ladrones, prudentes, feroces y solidarios, tan decididos a vivir y tan despiadados adversarios en la lucha por la vida; de esos griegos que han sobrevivido, en las cocinas y en las canteras; y que hasta los alemanes respetan y los polacos temen. Hace tres años que están en el campo, y nadie mejor que ellos sabe lo que es el campo; ahora están reunidos, apiñados en un corro, hombro contra hombro, y cantan una de sus cantilenas interminables.

Felicio, el griego, me conoce:

—L'année prochaine à la maison! — me grita, y añade-: ...à la maison par la cheminée!

Felicio ha estado en Birkenau. Y siguen cantando. Y dan golpes con los pies rítmicamente, y se embriagan de canción (I, 76-77) ${ }^{7}$

Las canciones, al igual que los poemas y las conversaciones con amigos, simbolizan la vida libre, la que llevan los que no son prisioneros y la que estos tenían antes del cautiverio. Por eso Levi las detecta por contraste en el comportamiento de las mujeres alemanas que trabajan en el laboratorio químico en el que él está destinado por haber avalado en un examen su competencia, ya que estaba en posesión del título de doctor en esa ciencia, pues ellas, arias, son libres y él, judío, aunque cuente con su doctorado y sus conocimientos, está preso: "Estas chicas cantan, como cantan todas las chicas de todos los laboratorios del mundo, y esto nos hace profundamente desgraciados. Conversan entre sí, hablan del racionamiento, de sus novios, de sus casas, de las próximas fiestas..." (I, 150). Esas canciones y esos diálogos, tan normales y frecuentes entre personas libres, le obligan a recordar su existencia antes de que le detuvieran, cuando él mismo cantaba y podía disfrutar de la música, y no odiarla:

\footnotetext{
${ }^{7}$ Es evidente que Levi miraba con respeto a este grupo de deportados meridionales: "Estos pocos supervivientes de la colonia judía de Salónica, la del doble lenguaje, español y helénico, y de las múltiples actividades, son los depositarios de una concreta, terrena, cómplice sabiduría en la que confluyen las tradiciones de todas las civilizaciones mediterráneas. Que esta sabiduría se resuelva en el campo con la práctica sistemática y científica del hurto y del asalto a los cargos y con el monopolio de la Bolsa de los trueques, no debe hacer olvidar que su repugnancia por la brutalidad gratuita, su asombrosa conciencia de la subsistencia de una, cuando menos potencial, dignidad humana, hacían de los griegos del Lager el núcleo nacional más coherente y, bajo este punto de vista, el más civil” (I, 85).
} 
El año pasado a esta hora yo era un hombre libre: fuera de la ley pero libre, tenía un nombre y una familia, tenía una mente ávida e inquieta y un cuerpo ágil y sano. Pensaba en muchas cosas lejanísimas: en mi trabajo, en el final de la guerra, en el bien y en el mal, en la naturaleza de las cosas y en las leyes que gobiernan la conducta humana; y además en las montańas, en cantar, en el amor, en la música, en la poesía (I, 151)

Lo normal será, así pues, que cuando vuelva la libertad, también regrese la música y vuelvan las canciones, y eso es lo que de hecho sucede cuando llegan al campo los soldados del ejército rojo. En efecto, después de la liberación y de la visita de unos enfermos al campo de los prisioneros de guerra ingleses, aquellos vuelven a su barracón con una carretilla cargada de productos alimenticios y aguardiente. Cuando han saciado el hambre y la sed, estalla el canto: "Por la tarde, en la barraca 14 estaban cantando” (I, 177). Así también, en la primera noche de libertad, todavía convalecientes en las literas de otra barraca aislada de aquella enorme enfermería, Levi ha de asistir al llanto del viejo Thylle, que en busca de compañía se sube a su litera y, habiendo dejado de llorar, le dice “¡diez ańos!”. El escritor italiano añade: “y después de diez años de silencio, con un hilo de voz estridente, grotesco y solemne a un tiempo, se puso a cantar la Internacional, dejándome turbado, desconfiado y conmovido" (II, 15).

La música puede ser también, por consiguiente, la mejor respuesta de los humanos al silencio forzado al que los nazis sometieron a los mismos alemanes que tenían otras opciones políticas. Se torna así no en una infame hechicera, sino en una muestra inequívoca de la humanidad que compartimos y que nos une a todos los miembros de la especie humana, como no se cansó de repetir Robert Antelme, nos une al género humano al que todos pertenecemos, seamos alemanes o italianos, arios o semitas: sin palabras, sin diferencias idiomáticas, la música también puede generar fraternidad y es, en este sentido, genuinamente internacional, es la internacional. Tan internacional como uno de los medios con los que se constituye y expresa: el silencio, los silencios. 